\title{
Low mortality and severe complications despite high influenza burden among Hong Kong children
}

\author{
Hong Kong Med J 2019;25:497-8 \\ https://doi.org/10.12809/hkmj197958
}

To the Editor-Every winter, the Hong Kong Hospital Authority appeals to the public for understanding amid overcrowding at the city's public hospitals as influenza cases spike. The Centre for Health Protection (CHP) has been reporting the annual influenza burden and confirms that, in Hong Kong, there has been no significant increase in mortality among patients with influenza aged $<18$ years. Among paediatric patients, there are few severe cases and few deaths each year, usually among unimmunised children, in a population of around 1.5 million children and youths. ${ }^{1-5}$

The burden on public hospitals may be due, in part, to the low immunisation rate among children. Paediatric patients with severe influenza may require in-patient stays of 1 to 2 days. Paediatric patients who require urgent care must be prioritised and should not have to wait for $>8$ hours pending assessment or admission. Yet this may be inevitable if the department becomes overcrowded with too many competing demands on staff time. Ideally, patients should be seen initially by their family doctors and stay home to recover if their admission is not necessary or urgent.

Excessive and exaggerated media publicity over the relatively few annual influenza-related deaths and severe cases may contribute to public panic, with increased admissions, some of which may be unnecessary, leading to higher workloads for medical staff-all of which may serve to delay the assessment of severe cases. The media may constructively spend their energy in lobbying for immunisation in the local healthcare system to help to relieve the pressure on an already over-burdened and under-funded hospital healthcare system.

Seasonal influenza continues to cause

TABLE. Cases, severe cases and mortality due to seasonal influenza in Hong Kong ${ }^{6}$

\begin{tabular}{lcccc}
\hline Year & $\begin{array}{c}\text { Influenza } \\
\text { deaths, } \\
<\mathbf{1 8} \text { years }\end{array}$ & $\begin{array}{c}\text { Severe cases, } \\
<\mathbf{1 8} \text { years }\end{array}$ & $\begin{array}{c}\text { Severe cases, } \\
\text { all ages }\end{array}$ & $\begin{array}{c}\text { Seasonal } \\
\text { influenza cases, } \\
\text { all ages }\end{array}$ \\
\hline 2012 & 2 & 18 & & \\
\hline 2013 & 1 & 13 & & \\
\hline 2014 & 1 & 25 & 322 & 12161 \\
\hline 2015 & 1 & 22 & 854 & 23004 \\
2016 & 3 & 27 & 505 & 21218 \\
\hline 2017 & 3 & 24 & 672 & 28131 \\
\hline 2018 & 1 & 31 & 786 & 23462 \\
\hline
\end{tabular}

significant morbidity, but not mortality or intensive care admissions among children and young persons in Hong Kong. Influenza-related morbidity in terms of severe cases in patients aged $<18$ years has increased but the total number is still low $\left(\right.$ Table $\left.^{6}\right)$.

Immunisation rates can be enhanced using targeted strategies for healthcare practices and providers. Sufficient vaccine supply should be secured annually. School vaccination teams provide excellent timely delivery of vaccines to schoolchildren. Private medical practitioners are also generally willing to be involved and their involvement would help to relieve the intense manpower needed for influenza vaccination prior to (and sometimes during) the annual influenza season.

Influenza is a serious public health concern globally. Public misunderstandings, unfounded fears, and various myths surrounding influenza, influenza vaccines, and other essential childhood immunisations must be addressed. Prevention and prompt diagnosis and treatment of influenza reduces morbidity. ${ }^{7}$ Physicians, school teachers, parents, and policy makers should cooperate to effectively coordinate and deliver the annual seasonal influenza immunisation programme, as well as the management of acute influenza infections that present to our healthcare services. Children with infectious diseases who are nevertheless still relatively well should try to recover at home and avoid school, nurseries, or other public places, to prevent the spread of infectious diseases such as influenza.

\section{Author contributions}

All authors have contributed to the concept, acquisition of data, analysis of data, drafting of the article, and critical revision for important intellectual content. All authors had full access to the data, contributed to the study, approved the final version for publication, and take responsibility for its accuracy and integrity.

\section{Conflicts of interest}

All authors declared no conflicts of interest.

\section{Funding/support}

This report received no specific grant from any funding agency in the public, commercial, or not-for-profit sectors.

1,2 KL Hon *, MB, BS, MD

${ }^{3}$ Julian W Tang, PhD, FRCPath 


\section{Department of Paediatrics and Adolescent Medicine, The Hong Kong Children's Hospital, Kowloon Bay, Hong Kong \\ ${ }^{2}$ Department of Paediatrics, The Chinese University of Hong Kong, Shatin, Hong Kong \\ ${ }^{3}$ Department of Infection, Immunity and Inflammation, University Hospitals of Leicester NHS Trust, United Kingdom \\ *Corresponding author: ehon@hotmail.com}

\section{References}

1. Chan PK, Tam WW, Lee TC, et al. Hospitalization incidence, mortality, and seasonality of common respiratory viruses over a period of 15 years in a developed subtropical city. Medicine (Baltimore) 2015;94:e2024.

2. Hon KL, Luk MP, Fung WM, et al. Mortality, length of stay, bloodstream and respiratory viral infections in a pediatric intensive care unit. J Crit Care 2017;38:57-61.

3. Hon KL, Leung TF, Cheung KL, Ng PC, Chan PK. Influenza and parainfluenza associated pediatric ICU morbidity.
Indian J Pediatr 2010;77:1097-101.

4. Hon KL, Leung E, Tang J, et al. Premorbid factors and outcome associated with respiratory virus infections in a pediatric intensive care unit. Pediatr Pulmonol 2008;43:275-80.

5. Chiu SS, Kwan MY, Feng $\mathrm{S}$, et al. Influenza vaccine effectiveness against influenza A (H3N2) hospitalizations in children in Hong Kong in a prolonged season, 2016/17. J Infect Dis 2018;217:1365-71.

6. Cheung E. Girl, 3, becomes first child fatality winter flu season in Hong Kong. South China Morning Post 2018 Jan 15. Available from: https://www.scmp.com/news/hongkong/health-environment/article/2128294/girl-3-becomesfirst-child-fatality-winter-flu. Accessed 28 May 2019.

7. Muthuri SG, Venkatesan S, Myles PR, et al. Effectiveness of neuraminidase inhibitors in reducing mortality in patients admitted to hospital with influenza A H1N1pdm09 virus infection: a meta-analysis of individual participant data. Lancet Respir Med 2014;2:395-404.

\section{Re: Per urethral insertion of foreign body for erotism: case reports}

Hong Kong Med J 2019;25:498

https://doi.org/10.12809/hkmj198204

To the Editor-It was a pleasure to delve into the detailed article by Mak et al, ${ }^{1}$ published in the August 2019 issue of the Hong Kong Medical Journal. The accounts for the diagnosis and treatment of urethral polyembolokoilamania were comprehensive and interesting. However, to general practitioners, emergency physicians and general surgeons, anorectal polyembolokoilamania could well be the more commonly encountered problem.

We first encountered this disorder in Hong Kong in 1986 when the topic of sex, let alone objectassisted auto-eroticism, was still taboo. Some patients would rather perish than seek medical help. Gossiping about the patients' presentation was, regrettably, commonplace among the attending healthcare professionals. Unfortunately, the stigma persists: patients in recent years still display apparent uneasiness when discussing the condition, despite the more liberal social environment.

We would like to share a few lessons learned over the decades of dealing with anorectal polyembolokoilamania. First, a professional and non-judgemental attitude is of utmost importance in treatment. It ensures that patients are not deterred from seeking treatment due to stigmatism or potential embarrassment and reduces physical and emotional complications as a result of delayed treatment.

Second, for the removal of large and slippery objects from the upper rectum, we found no suitable grasping forceps among the standardised minor general surgery instruments provided. The best instrument to use is one available from basic gynaecology instrument sets: the 9" Teale Vulsellum

Forceps. This was discovered when facing great difficulty in extracting a large silicon rod from a patient's upper rectum. Ever since that experience, we have consistently resorted to this instrument and found that it had expedited subsequent procedures; including the removal of a large slippery (from lubricant used by the patient) and activated vibrator.

\section{Author contributions}

All authors contributed to the concept, acquisition and analysis of data, drafting of the article, and critical revision for important intellectual content.

\section{Conflicts of interest}

The authors have no conflicts of interest to disclose.

\section{Funding/support}

The authors received no funding source/grants or other material support for the study.

\section{JR Khoo \\ ${ }^{1}$ Gabriel TC Wu \\ ${ }^{2}$ Benson KF Yeung *, FHKAM (Surgery)}

Li Ka Shing Faculty of Medicine, The University of Hong Kong, Pokfulam, Hong Kong

2 Private Surgeon, Hong Kong

*Corresponding author: dr.bensonyeung@gmail.com

\section{Reference}

1. Mak CW, Cho CL, Chan WK, Chu RW, Law IC. Per urethral insertion of foreign body for erotism: case reports. Hong Kong Med J 2019;25;320-2. 